\title{
UV-screening pigment enabling ancient photosynthesis
}

\author{
YANNICK J. LARA ${ }^{1}$, ANDREA MCCANN ${ }^{2}$, CEDRIC \\ MALHERBE $^{2}$, CAMILLE FRANÇOIS ${ }^{3}$, CATHERINE F. \\ DEMOULIN $^{1}$, MARIE CATHERINE SFORNA ${ }^{1}$, GAUTHIER \\ EPPE $^{2}$, EDWIN DE PAUW ${ }^{2}$, ANNICK WILMOTTE ${ }^{2}$, \\ PHILIPPE JACQUES ${ }^{2}$ AND EMMANUELLE J. JAVAUX ${ }^{1}$ \\ ${ }^{1}$ Université de Liège \\ ${ }^{2}$ University of Liège \\ ${ }^{3}$ Commission for the Geological Map of the World \\ Presenting Author: ylara@uliege.be
}

Cyanobacteria are an ancient bacterial phylum of phototrophic gram-negative bacteria. Members of this phylum have played an important role in the evolutionary history of Life. Ancestral cyanobacteria are partly responsible for the Great Oxygenation Event (GOE). They are also involved, as ancestor of the plastids, in the endosymbiosis which led to the diversification of photosynthetic protists and plants.

Ancestral cyanobacteria were exposed to high doses of both UV-C ( $>280 \mathrm{~nm})$ and UV-B $(280-350 \mathrm{~nm})$ radiations, due to the lack of $\mathrm{O}_{3}$ in the atmosphere. Such radiations are known to provoke irreversible impacts on cells by directly damaging nucleic acids, proteins and lipids, or by creating reactive oxygen species (ROS). They also inhibit photosynthesis by damaging the D1 reaction center of the photosystem II. Without atmospheric irradiation protection, ancestral cyanobacteria, if already present, would have needed to develop original strategies to protect their photosystem and cellular integrity (e.g. motility, ROS-binding enzymes, fast DNA repair mechanisms, UV-absorbing molecules). Among these strategies, the biosynthesis of photoprotective pigments may have helped cyanobacteria and other bacteria to colonize shallow waters and terrestrial habitats before $1.9 \mathrm{Ga}$, age of the oldest unambiguous fossils of benthic cyanobacteria.

Here, we present new spectroscopic and spectrometric features of the enigmatic halochromic cyanobacterial pigment, gloeocapsin. We also evidence its synthesis in at least three cyanobacterial lineages suggesting the production of gloeocapsin by a common ancestor or the occurrence of lateral gene transfers. This probable early UV-protection pigment is a useful biosignature that could be traced back in the fossil record. 